\title{
Civilisations
}

Revue internationale d'anthropologie et de sciences

humaines

49 | 2002

Pain, fours et foyers des temps passés

\section{The chemical identification of ancient british}

bread flours

Encountering and overcoming some of the obstacles

Frances McLaren et John Evans

\section{(2) OpenEdition}

Journals

Édition électronique

URL : http://journals.openedition.org/civilisations/1427

DOI : $10.4000 /$ civilisations. 1427

ISSN : 2032-0442

Éditeur

Institut de sociologie de l'Université Libre de Bruxelles

Édition imprimée

Date de publication : 3 juin 2002

Pagination : 169-182

ISBN : 0009-8140

ISSN : 0009-8140

Référence électronique

Frances McLaren et John Evans, "The chemical identification of ancient british bread flours »,

Civilisations [En ligne], 49 | 2002, mis en ligne le 14 mai 2009, consulté le 21 avril 2019. URL : http://

journals.openedition.org/civilisations/1427 ; DOI : 10.4000/civilisations.1427

Ce document a été généré automatiquement le 21 avril 2019

(c) Tous droits réservés 


\section{The chemical identification of ancient british bread flours}

Encountering and overcoming some of the obstacles

Frances McLaren et John Evans

Research into the history of wheat and rye was carried out under a two year NERC grant No: GR3 /9574 which is acknowledged. We also wish to express our grateful thanks to all those who have contributed to this study including: Mrs Lesley Stanley for providing the $19^{\text {th }}$ century sandwich, Peter Murphy for providing the Anglo-Saxon buns for analysis. Hara Procopiou and Dr. Francoise Formenti for friendly discussions. Professor Gordon Hillman for providing a wide range of cereals from his reference collection at The Institute of Archaeology. Julia Freeman and Sue Harrison, for reading drafts of the script. Lastly Dennis Wheatley and Jim Emmins for their quiet, friendly tutorials on the vagaries of chemical analyses.

\section{Introduction}

The history of food is an important part of a social heritage. Old recipes make interesting reading but how representative are they of past foods? What were the foods of the British Isles really like? Did our forebears have plain rustic diets or perhaps our ancestors were more cosmopolitan in their tastes and had access to a wide variety of foods including foreign imports such as olive oil?

Dark winter days and unreliable summer weather have probably influenced the daily diet of people in the British Isles far more than the sway of our EU overlords in the days when we had European unity. Once agriculture was established in the British Isles, cereals undoubtedly formed the basis of many meals eaten in the British Isles (Grube 1934).

The British Isles have a relatively large amount of early historical writings that includes references to bread but this documentary evidence is mainly confined to ecclesiastical concerns. Consequently the economic evidence is fragmentary and often ambiguous, particu-larly when the subject was of limited interest to clerics (Ashley 1926; Green 1984). Nevertheless, there were a number of laws concerning the adulteration of bread flours (Ashley 1926). 
Bread making is arguably the most popular method of producing a cereal food ever to have been discovered. For breadmaking the basic ingredients are flour, water and yeast which are needed in set proportions of $100: 65: 2$ regardless of whether the final outcome is a flat bread or a standard white yeast loaf (Larsson 1994 :194). Variation in the finished bread product primarily comes with the type of flour used or the addition of optional inclusions including salt. The best quality bread would have been made entirely of wheat flour while inferior breads would have included increasing amounts of bran and germ (Grube 1934; Moritz 1958). It has also been documented that bread flour was produced from a variety of other plant sources including barley, oats, rye, hazelnuts, pulses, chest-nuts or tubers. In times of famine even toxic ash keys and acorns were converted into flour (Hagen 1992).

The addition of sweet or savoury spices and flavourings can also add diversity to bread mixes. Again, the nature of the added ingredients usually depended on the social standing of the consumer or whether the bread was made for a special occasion such as a religious festival. Oil/fat supplements were added for those who could afford them and popular additions included butter, milk, meat fat or fish oils (Hagen 1992). The ingredients are mixed together into dough and allowed to ferment.

Fermentation has been successfully used to leaven and flavour bread for well over 5.000 years (Wood 1995). There are two possible fermentation reactions produced either by a wild air born yeast or lactic acid bacteria. Bread made by the addition of a starter is fermented by lactic acid bacteria and is known as sourdough bread. It is the most common method of making bread that contains rye flour (David 1982). Occasionally two fermentation periods were applied: half of a combination of grain/flour water and a starter yeast was mixed and fermented as a "spon " or sponge, to which was added the remaining mixture for a second period of fermentation (David 1982).

Historically, bread fermentation techniques varied considerably between English, Irish and Scottish bakers (Braun 1903). In England until 1897, the historical evidence examined by Braun suggested that brewers' or distillers' yeast be used almost exclusively to initiate fermentation.

Commercial baking in the British Isles has always tended to be on a small scale (Braun 1903). There is little evidence to suggest that the bakers of the British Isles have ever produced the large range of bread rolls and buns that are commonly found in the rest of Europe. The Irish and Scottish bakers tended to make a wider range of breads than the English by using more than one type of fermentation process. Irish bakers preferred to use both a brewers' or distillers' yeast ferment and a spon ferment. While Scottish bakers used both these methods but preferred to use a Parisian barm (a variation on a spon ferment using very fresh ale yeast or malt and flour for fermentation), even though this method required a considerable fermentation time and a large quantity of salt to prevent the dough from going sour.

Home baking was very popular in British and Irish households, particularly using griddle irons. An alternative method of bread making for the immediate family probably involved the use of inverted pots over an open fire (O'Danachair 1983).

Archaeological evidence to support these historical methods of home baking in the British Isles is sparse. Large half pots were recently uncovered during Roman excavations at Elms Farm, Essex, which were found dug at angle into the ground (Atkinson 1995). It has been postulated that these pots may have been used as tannur ovens for making flat breads. Here, confirmatory analyses need to be undertaken though. 
A small number of instantly recognisable ancient breads have been recovered from archaeological excavations in the British Isles. The first notable find of British bread was the discovery of sticky buns from Iron Age Glastonbury (Helbaek 1952). Recently, spelt bread was recovered from Fishbourne Roman Palace (Carruthers 1991), bread crumbs were recovered from Roman Richborough and eleven Anglo Saxon sourdough loaves were found during excavations at the Buttermarket, Ipswich Murphy 1990. Although the quantity of ancient breads of the British Isles may be poor,they were recovered from either domestic localities or areas which suggested they were intended for consumption. Most of the Continental and Egyptian breads were probably funeral offerings not necessarily destined for human consumption (Hansson 1994; Hajnalova 1989; Samuel 1994) and therefore, the British Isles material makes ideal study material to investigate as part of a long term investigation into the history of food.

Chemical analysis of ancient foods has a long history of investigation extending back to the middle of the last century when the finds from the Swiss Lakeland sites were uncovered (Heer 1866). Specific interest in examining the contents of European bread began with Rosendahl's (1912) investigation of Swedish bread. For the most part, past chemical investigations into ancient foods have tended to concentrate on the fat content because lipids are generally recognised to be the most stable of all surviving biomolecules (von Stoker 1938 ; Needham \& Evans 1987 ; Hansson 1994).

Advances in morphological techniques and analytical chemistry now permit the routine examination of modest amounts of organic material which were previously thought too small to handle. We have been successful in removing sufficient extract from only twenty milligrams of a char sample. Unless there is morphological guidance, there is no easy way to simply prove the identity of an organic residue, unless uniquely specific substances are present. Morphine, for example, is the prime alkaloid found in opium, however its presence does not necessarily mean that the poppy itself - Papaver somniferum L. is present.

Most natural food products such as milk or green vegetables are very complex mixtures. Plant waxes are a heterogeneous group. Leaf waxes are subject to wide phenotypic variation and further more the wax can vary from leaf to leaf, season to season and year to year (Bianchi 1995). Fortunately for those interested in farinaceous foods, cereal grains are more uniform and can be separated into separate species (McLaren et al.1991; Hillman et al. 1993). Tetraploid and hexaploid wheats have been success-fully separated on the basis of their waxy coats alone (Bianchi 1995). It is, therefore probable that most flours can be identified but it is unlikely that many other plant inclusions - particularly if there are no morphological clues - will ever be identified beyond the family level, even with the most sophis-ticated analytical tools available.

\section{The programme of chemical analyses}

It is essential that a combination of both morphological (including Scanning Electron Microscopy - SEM) and chemical techniques are implemented on ancient breads in order to acquire the maximum amount of information. Neither type of analysis should stand alone. Food analysers should also make use of ethnographical, historical and archaeological records. However, for the sake of brevity, this paper is primarily confined to some of our efforts to chemically identify ancient farinaceous flours and to some background chemical research. 
After morphological inspection of a residue, the programme of chemical investigation normally begins with X-ray Fluorescence Spectrometry (XRF) for an indication of the inorganic content of a sample. If the specimen has an unusually high sodium content or if there is an indication that chlorides may be present then it is possible that there was a salted product (Evans \& Hill 1983). A simple chloride test would help to clear the uncertainty. At the other extreme, the chlorides could be evidence of insecticide contamination, which would be confirmed by analysis of the soils local to the residue.

Following the XRF analysis, the samples are subjected to an overview by Infrared (IR) analysis (for method see McLaren et al. 1991). IR spectra generally produce a good overall view of a sample's content (McLaren et al. 1991; Hillman et al. 1993). The initial view indicates whether either organic or inorganic materials dominate the sample. Certain substances readily lend themselves to instant identification, for example, beeswax has a very characteristic IR spectrum (Needham \& Evans 1987). Having obtained a general picture of the sample content, various avenues of enquiry may need to be pursued. For example, if unusually high amounts of phosphate and sulphide were indicated then a test for albumin should be undertaken to ascertain the possible presence of eggs in the sample (Evans \& Hill 1983). However, before we examined ancient farina-ceous foods we carried out a series of short study programmes to ensure the charred material could be successfully analysed.

\section{Contamination studies}

Almost certainly from the period when the original food was processed until the time when it was uncovered during archaeological excavation, the ancient residue will have been subjected to taphonomic processes which would bring the material in contact with a variety of unknown chemical mixtures in the ground. There is a distinct possibility that there may have been a chemical exchange between the organic residue and its environment. Ideally some of the local soils should also be examined for comparative purposes in order to make some sense of the past taphonomic processes.

Charring experiments in /on archaeological soils and past investigations of ancient chars (particularly charred grains) have also revealed that the problem of decomposition (particularly post excavational) is less serious than was originally supposed. Examina-tion of organic residues from pottery also suggests that any exchange may be dependent on the age of the organic residue and/or the type of deposit from which the sample derives (Evans 1990). In the case of pottery, many of the decomposition problems can be resolved if it is possible to remove areas of exposed surfaces - typically $2 \mathrm{~mm}$ depth of pottery surface. Although pottery residues, where there is no surviving char, can have decompositional problems the same does not appear to hold true for charred grains and food. Examination of a number of chars (biological specimens and foods) by IR and Gas Chromatography (GC) over the years has shown that any problems associated with contamination and degeneration really begin when specific components of the extract are targeted (see below). Until that time the compounds extracted from ancient organic residues appear to have reached a relatively stable equilibrium.

To test our observations concerning the stability of extracts during IR detection, compounds, which were first extracted from ancient and modern seeds during the period 1987 to 1990 have been periodically re-examined by IR to see if there were observable changes over time. To date, we have yet to see any major shifts in the major IR peaks, 
only loss of the occasional small peak. A sub-sample of these old extracts was also sent to the University of Liverpool three years after the initial extractions. Fourier Transfer Infrared (FTIR) spectra at Liverpool again showed the same basic IR peak patterns as were observed in the original spectra.

\section{IR studies of food processing and bread making}

As part of an investigation into the chemotaxonomy of plants, relatively large data bases have been built up. Of prime importance to the investigation of farinaceous foods is our self compiled IR data base, which consists of a wide range of cereal species. A large proportion of this IR database consists of wheats and ryes. The first query posed when we chemically investigated ancient breads was, how similar were the chemical fingerprints of processed foods when compared to those of whole grains of cereals.

If grains or flour are badly stored for a long time, the action of lipase, bacteria, fungi or microfauna could result in significant changes between the spectra of a raw grain and that of a processed loaf. The lipids of bacteria, fungi and other microfauna are identifiable by GC/MS because they have distinct lipid patterns not found in cereal plants (Harwood \& Russell 1984). Furthermore, the study of Farag et al. (1986) on the effects of four fungi on wheat suggested that there should be no difficulty with the identification of fungal activity. We have examined some weevil infested Triticum dicoccum (Schrank.) Schlübl. (commonly called emmer) by the less sensitive technique of IR and found very little variation between the spectra of contaminated and uncontaminated grain.

The milling of wheat and rye flours results in a general increase of the carbohydrate content but also in a decrease of the other chemical constituents (McCance et al. 1945). We have in the past examined grind-stones, for example, a local Essex grindstone (ref: WEA4). The extract from the working surface area produced a general cereal type of IR spectrum but it also included two peaks of unknown origin between $1500 \mathrm{~cm}^{-1}$ and $1300 \mathrm{~cm}^{-1}$. Further studies are in progress but as yet we are unable to separate the obvious multipurpose usage this mortar was put to. In addition, a major investigation of the effects of storage and milling on cereals is at present being pursued by Procopiou and Formenti.

Our study of ancient breads began with a simple investigation to see how baking affected the IR spectra. A home produced bread was made with a modern strong flour, commercial yeast and water. We generally found that there was a good correlation between the spectra of the flour and the bread (see Fig. 1). 
Fig. 1 : Gray : Propan-02-01 extract of modern « strong » breadmaking flour (IRFM 414 :62) Black : Propan-02-01 extract of modern bread made from « strong » flour (IRFM 392:60)

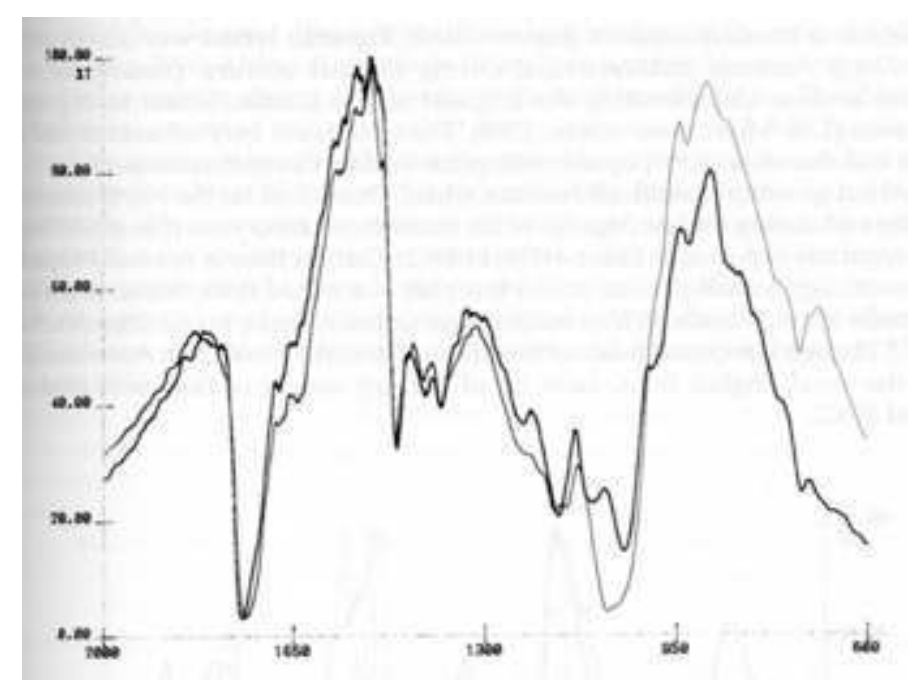

The hexane spectrum only showed a variation around $1700 \mathrm{~cm}^{-1}$ to $1400 \mathrm{~cm}^{-1}$. In this area the raw flour spectrum produced water peaks that did not survive cooking processes. The chloroform spectrum of the bread extract showed that some degradation had occurred because there was a general flattening of peaks in the spectrum between $1200 \mathrm{~cm}^{-1}$ and $700 \mathrm{~cm}^{-1}$. Peak flattening in the same region was slightly more accentuated in the propan-02-ol extract.

A possible reason for this general peak flattening in the chloroform and propan-02-ol spectra may simply be due to the rearrangement of molecules caused by the processing and subsequent cooking of the bread. Unfortunately IR spectroscopy alone cannot resolve the exact reasons for the slight variation between the spectra and additional chemical analyses have yet to be carried out on these samples. However, it was felt that the variation between the spectra was not great enough to cause concern. We, therefore felt fairly secure in using our cereal databases to identify ancient foods.

\section{A $19^{\text {th }}$ century sandwich}

A freeze dried sandwich, recently found when a house was being restored in Wales, was one of the first breads we examined. The sandwich was found under the floorboards of a first floor room that had in effect been freeze dried. The sandwich was wrapped in a copy of the Liverpool Echo. Initial examination including SEM suggested that the sandwich had a fat filling. A corner of the bread where there was no evidence of any spread was detached from the sandwich.

The IR spectra suggested that the sandwich bread was primarily made from Triticum durum Desf. (commonly called durum or macaroni wheat) - a hard tetraploid wheat (Fig. 2). The variety that had the best IR fit with the sandwich is called « Kubanka » a Russian word for durum wheat. Kubanka wheat was introduced to both North America and Australia, during the last century, presumably with Russian settlers. Unfortunately, the origin(s) of this Russian wheat is, at present unknown (T. E. Miller pers. comm. 1990). The wheats are very tolerant of arid climates and therefore, very popular with plant breeders in both continents. 
Fig. 2 : Gray : Propan - 02- 01 extract of $T$. durum Desf. - « Kubanka » (IRMGF 1538:365) Black: Propan - 02- 01 extract of ancient Welsh sandwich (BRDP)

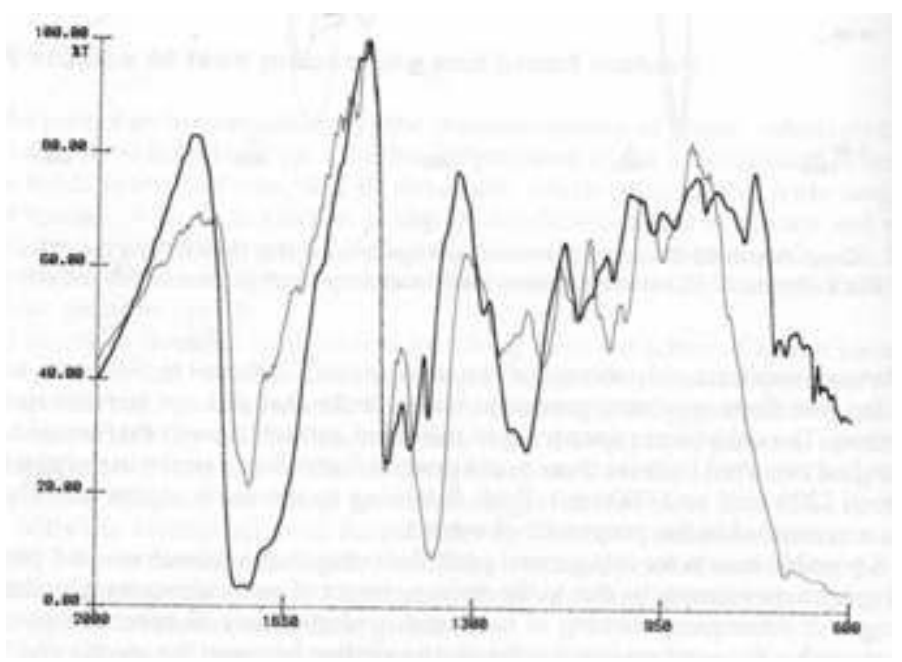

Wheat growing (specifically durum wheat) flourished on the North American prairies and during the last decades of the nineteenth century, surplus stocks began to be regularly exported to Europe (David 1982). Durum flour is normally regarded as too "strong » to make bread unless it is part of a mixed flour. About at the time the sandwich was made, British bakers were urged to make bread from American flour. Although it required twice as much water to make a loaf from American flour than the usual English flour, more bread per dry weight of flour was produced (David 1982).

Samples of the filled area of the sandwich have also been subjected to GC/MS in order to determine the filling. At present until confirmatory work is completed we suspect the sandwich consisted of bread and dripping.

\section{Saxon loaves}

Three samples from eleven charred «buns » or loaves were recovered from Mid-Saxon excavations of a stable (circa $8^{\text {th }}$ century AD) at the Buttermarket site in Ipswich, Suffolk are at present under investigation (Murphy 1990).

IR analysis immediately suggested that the flour in the buns was composite in origin, which would need discriminate IR analysis to separate the mixture (Martin 1966; McLaren 1990). Using discriminate IR analysis is rather like peeling an onion. The original spectrum shows a composite of the total bread mixture. Possible flour mixtures were extracted and run against the unknown ancient bread mixtures. If the resulting spectrum is a straight line then you have identified the mixture but if peaks are produced then this shows the ancient and modern mixtures do not match. Alternatively, if you suspect the mixture contains just two elements such as bread wheat and rye the unknown can be run against either one of the elements. The resulting spectrum should show some resemblance to the other cereal inclusion. The buns appear to be made of a mixture of rye Secale cereale $\mathrm{L}$. and two wheats, a tetraploid and hexaploid (possibly T. dicoccum and T .aestivo-compactum Host.) (McLaren 1990). 
Fig. 3 : Gray : Propan- 02- 01 extract of $T$. dicoccum (Shrank) Schülb (IRFM 1472/373) Black : Propan- 02- 01 extract of Anglo Saxon Bread - rye sour dough bread (IRFM 419)

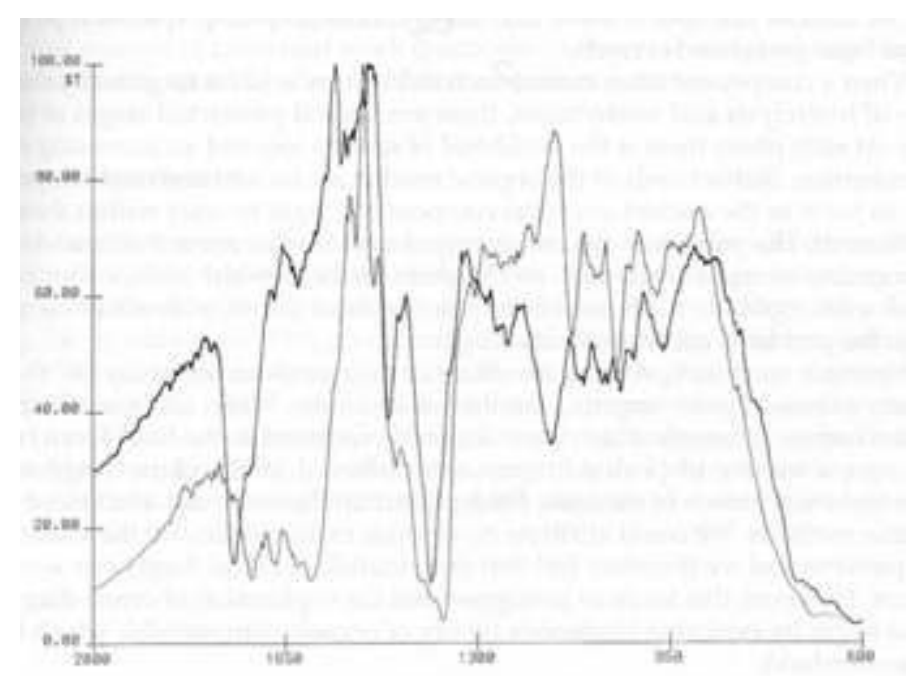

\section{Analysis of ancient farinaceous material by gas liquid chromatography (GLC) and gas chromatography/mass spectroscopy (GC/MS)}

Recently there has been a tendency to rely almost totally on the more sophisticated methods of analyses such as GC/MS when investigating organic residues (Oudemans \& Boon 1991 ; Evershed et al. 1992). However, a problem immediately arises because these methods target specific compounds. Can the GC/MS pattern of fatty acid methyl esters (FAMES), for example, really be representative of the whole food? Experience has shown us that a destructive method such as GC/MS should be an end point of an investigation rather than a beginning. It is far better to accomplish as many non-destructive analyses as possible at the start of a chemical investigation of organic residues. Both inorganic and organic analyses are needed to complete the picture. Additionally, it is not unknown for degraded metal objects to be sent to us as possible food chars.

In essence GLC and GC/MS are the most refined finger printing tools available for the analysis of small samples of organic material. However, their ability to distinguish even small quantities in a sample poses a problem because of the ever present problems of contamination and diagenesis (chemical breakdown). Although, modern contamination is in a sense relatively easy to recognise and can be dealt with. The most common contamination of a sample is usually plasticisers, which are used for hardening plastic (such as bottle stoppers or plastic bags). Today, most modern laboratories are so full of plastic items that their air is overflown with plasticisers, which are impossible to remove from a chemical sample. Therefore, evidence of plasticiser chains usually appears on so many occasions that it can be used as markers to show that the chromatographic preparation procedures had been performed correctly.

When a component of an extract such as the fatty acids is targeted by the processes of hydrolysis and methylation, there are several protracted stages of preparation. At each phase there is the likelihood of sample loss and an increasing risk of contamination. Stable bonds of the organic residue are broken and new compounds begin to form as the 
ancient chemical components begin to react within their new environment. The process of diagenesis begins to accelerate anew. Fortunately there are a number of rapid smallscale methylation methods which reduce preparation time. For example we have used Bhatty \& Rowland (1990) with some success to reduce the problems associated with diagenesis.

We began an investigation of the effects of diagenesis on cereals by GC as a preliminary exercise before targeting the cereals in foods. When GC was carried out on sub-samples of cereals which were originally collected in the field about twenty years ago, a variety of peak patterns were observed in the chromatogram. The grains had been grown in the same field, picked on the same day and stored using the same methods. We could attribute no obvious expla-nations for the variation in peak patterns and we therefore feel that examination of cereal diagenesis would be of value. However, this leads us to suggest that the exploration of cereal diagenesis should begin by exploring biogenesis (decay of organic compounds), which is also little understood.

We have also begun to tackle the problems of identifying the FAMES of the in-fill of the welsh sandwich. Unfortunately, many common sub-stances produce similar FAMES patterns, for example, pork fat, olive oil and witchety grubs can all produce a similar fatty acid pattern (Williams 1949). Another common overlapping group includes both beef dripping and palm oil. Additionally all fats, whether they are of plant or animal origin, eventually degrade down to the same waxy substance known as adipocere (Morgan et al. 1970).

Obviously we need to be able to distinguish between processed animal and plant products. One obvious method for the detection of animal products has been the presence or absence of cholesterol (Rottländer \& Hartke 1982 and Charters et al. 1995). However, there is a strong possibility that cholesterol detected in amorphous ancient residues may be derived from a plant source. Cholesterol is now considered a precursor of ecdysteroids in plants. It has been confi-dently detected in a number of food plants of the family Chenopodiaceae including spinach (spinacia oleracea L.), beetroot (Beta vulgaris L.) and fat hen (Chenopodium album L.) (Coriocostet et al. 1993). Interestingly, Morgan et al. (1970) were unable to find a trace of cholesterol in bog butter, a substance which is always assumed to have an animal origin. Therefore, the use of cholesterol as an indicator of animal fats is at present of limited value to archaeology.

It may be that ratio patterns of triglycerides will prove a more valuable tool in examining ancient foods because each triglyceride is an usually complex mixture and can occur in isometric forms (Gunstone 1992). Two acids, such as palmitic and oleic, can form eight possible tri-acylglycerols. Unfortunately, a problem immediately appears on the horizon because triglycerides have such long separate retention times that at present they cannot be reliably separated and identified by conventional GC/MS analysis (Bahti 1987) at the levels encountered in archaeological material.

If we are to make progress in the analysis of ancient farinaceous foods then programmes of joint systematic studies should be undertaken, with people undertaking work in their specific areas of expertise. This would not only lighten the load of the vast amount of analytical work (particularly chemical analyses) required but also considerably speed up the acquisition of reference data. 


\section{BIBLIOGRAPHIE}

ARAG, R.S., MOHSEN, S.M., KHALIL, F.A. \& BASYONY, A.E., 1986. Effect of certain fungi on the lipids of wheat kernels, sesame and soybean seeds. Egypt. J. Food. Sci., 14/1, pp. 131-145.

ASHLEY, W., 1926. The bread of our forefathers. Clarendon, Press, Oxford.

ATKINSON, M., 1995. Elms Farm, Heybridge. Current Archaeology, 144, pp. 452-458.

BHATI, A., 1987. Fatty acid sequence in triglycerides and related compounds. In : R.J. HAMILTON and A. BHATI (eds.) Recent advances in chemistry and technology of fats and oils. London : Elsevier Applied Science, pp. 13-30.

BHATTY, R.S. \& ROWLAND, G.G., 1990. Measurement of a-linolenic acid in the development of edible oil flax. Journal of the American Chemistry Society, 67/6, pp. 364-367.

BIANCHI, G., 1995. Plant waxes. In : R.J. HAMILTON (ed.) Waxes : chemist-ry, molecular biology and functions. Dundee : The Oily Press, pp. 175-222.

BRAUN, E., 1903. The Baking industry in England. The Bakers Book , 1, pp. 182-192.

CARRUTHERS, W.J., 1991. Fishbourne Roman Palace, West Sussex : Carbonized plant macrofossils from garden features. Ancient Monuments Laboratory Report 130/91.

CHARTERS, S., EVERSHED, R.P., BLINKHORN, P.W. \& DENHAM, V., 1995. Evidence for the mixing of fats and waxes in archaeological ceramics. Archaeometry, 37/1, pp. 113-127.

CORIOCOSTET, M.F., CHAPUis, L., SCALLA, R., \& DELBECQUE, J.P., 1993. Analysis of sterols in plants and cell-cultures producing ecdysteroids .1. Chenopodium-album. Plant Science, 91, pp. 1 :23-33.

DAVID, E., 1982. English bread and yeast cookery. Harmondsworth : Penguin Books Ltd.

EVANS, J., 1990. Come back King Alfred, all is forgiven. In : W.R. BIERS \& P.E. MCGOVEN (eds.), Organic contents of ancient vessels : materials analysis and archaeological investigation, MASCA research papers in science and archaeology, pp. 7-9.

EVANS, J. \& HILL, H.E., 1983. Dietetic information by chemical analysis of Danish neolithic pot sherds : A progress report. In : A. ASPINALL and S.E. WARREN (eds.), Proceedings of the $22^{\text {nd }}$ symposium on Archaeometry, University of Bradford, pp. 224-228.

EVERSHED, R.P., HERON, C., CHARTERS, S. \& GOAD, L.J., 1992. Chemical analysis of organic residues in ancient pottery : methodological guidelines and applications. In : R. WHITE \& H. PAGE (eds.), Organic Residues in Archaeology: Their identification and Analysis. Proceedings of the conference organised by the United Kingdom Institute for Conservation, Archaeology Section, held at York, May $10^{\text {th }}$ 1990. United Kingdom Institute for Conservation Archaeology Section, pp.11-25.

GREEN, F.J., 1984. The archaeological and documentary evidence for plants from the medieval period in England. In : W. VAN ZEIST \& W.A. CASPARIE (eds) Plants and ancient man : Studies in palaeoethnobotany. Rotterdam : A.A. Balkema, pp 99-114.

GUNSTONE, F.D., 1992. Introduction. In : R.J. \& S. HAMILTON (eds.) Lipid Analysis, a practical approach. Oxford University Press, pp. 1-12. 
HAGEN, A., 992. A handbook of Anglo-Saxon food processing and consumption. Chippenham, Wiltshire : Anglo-Saxon Books.

HAJNALOVA, E., 1989. Evidence of a carbonized loaf of bread \& cereals from Bratislava-Devin. Slov. Archaeol., 37, pp. 89-104.

HANSSON, A-M., 1994. Grain-paste, porridge and bread. Ancient cereal based food. Laborativ Arkeologi, 7, pp. 5-20.

HARWOOD, J.L. \& RUSSELL, A. ,1984. Lipids in Plants and Microbes. London : George Allen \& Unwin.

HEER, O., 1866. Treatise on the plants of the Lake Dwellings. In : F. KELLER, trans. J.E. LEE : The Lake Dwellings of Switzerland and other parts of Europe. London.

HelBAeK, H., 1952. Early crops in Southern England. Proceedings of the Prehistoric Society 18, pp.194-233.

HILLMAN, G., WALES, S., MCLAREN, F., EVANS, J. \& BUTLER, A., 1993. Identifying problematic remains of ancient plant foods : a comparison of the role of chemical, histological and morphological criteria. World Archaeology, 25, pp. 1 :94-121.

LARSSON, K., 1994. Lipids molecular Organization, physical functions and Technical Applications, Dundee : The Oily Press.

MCCANCE, R.A., WIDDOWSON, E.M., MORAN, T., PRINGLE, W.J.S. \& MACRAE, T.F. (R.A.F.V.R.), 1945. The chemical composition of wheat and rye and of the flours derived there from. Biochemical Journal, 39, pp. 213-222.

MCLAREN, F.S., 1990. A critical view of the use of Infra-Red as an analytical technique for archaeological material : Loaves of our ancestors, Unpublished Msc. University of East London.

MCLAREN, F.S., EVANS, J. \& HILLMAN, G.C., 1991. Identification of charred seeds from SW Asia. In : E. PERNICKA and G. A. WAGNER (eds.), Basel : Birkhäuser Verlag. Archaeometry '90 : Proceedings of the $26^{\text {th }}$ International Symposium on Archaeometry, Heidelberg 1990, pp. 797-806.

MARTIN, A.E., 1966. Infra-red instrumentation and techniques. Amsterdam : Elsevier Publishing Company.

MORGAN, E.D., THORNTON, M.D. \& CELORIA, F., 1970. The composition of bog butter. Science and Archaeology , 2 and 3, pp. 20-24.

MORITZ, L.A., 1958. Grain mills and flour in Classical antiquity, Oxford : University Press.

MURPHY, P., 1990. Butermarket, Ipswich, Suffolk (IAS 3104) : carbonised loaves. Ancient Monuments Report No. 75/90.

NEEDHAM, S., \& EVANS, J., 1987. Honey and dripping ; neolithic food plant residues from Runnymede Bridge. Oxford Journal of Archaeology. 6, pp. 21-28.

O'DANACHAIR, K., 1983. Bread in Ireland. In : A. FENTON and T.M. OWEN (eds.) Food in perspective, Proceedings of the Third International Conference of Ethnographical Food Research. Cardiff, Wales, 1977. Edinburgh : John Donald Publishers Ltd., pp. 57-67.

OUDEMANS, T.F.M. \& BOoN, J.J., 1991. Molecular archaeology : analysis of charred (food) remains from prehistoric pottery by pyrolysis-gas chromatography/mass. Spectrometry J. of Analytical and Applied Pyrolysis, 20, pp. 197-227.

ROSENDAHL, H.V., 1912. Ärtbröd fran vikingatiden (800-150 e. Kr.). Svensk Botanisk Tidskrift 1911. $5 / 4$, pp. $432-433$ 
ROTTLÄNDER, R.C.A. \& HARTKE, I., 1982. The results of food identification by fat analysis. In : E.A. SLATER and J.A. TATE (eds.). Proceedings of the 16th International Symposium on Archaeometry, Edinburgh : National Museum of Antiquities of Scotland, pp. 218-223.

RUBE, F.W., 1934. Cereal foods of the Anglo-Saxons. Philological Quarterly XIII, pp.140-158.

SAMUEL, D., 1994. A new look at bread and beer. Egyptian Archaeology, 4, pp. 9-11.

STOKER, W., von 1938. Prehistoric organic remains. Antiquity, 12, pp. 82-86.

WILLIAMS, K.A., 1949. Oils (Fatty) and fats. In : I. HEILBRonet al. Thorpes Dictionary of Applied Chemistry (4th ed.) London : Longmans, IX, pp. 1-80.

WOOD, E.M., 1995. Wild sourdough fermentations. Laboratory Medicine, 26, pp. 11 :729-732.

\section{AUTEURS}

\section{FRANCES MCLAREN}

Department of Environmental Sciences \& Mathematics, University of East London,United Kingdom

\section{JOHN EVANS}

Department of Environmental Sciences \& Mathematics, University of East London,United Kingdom 